\title{
ADDRESSING STATELESSNESS THROUGH THE INTERNATIONAL CONVENTION ON THE ELIMINATION OF ALL FORMS OF RACIAL DISCRIMINATION ('ICERD’)
}

\author{
MICHIEL HOORNICK*
}

Discrimination is one of the root causes for deprivation and denial of nationality. This work presents an analysis of the right to nationality under art $5(d)$ (iii) of the International Convention on the Elimination of All Forms of Racial Discrimination and the interpretation of the obligations under art 2, related to this right by its monitoring body, the Committee on the Elimination of Racial Discrimination. This reflection focuses on obligations regarding deprivation of nationality, acquisition of nationality and other obligations to facilitate and fulfil the right to nationality of the individuals living within its jurisdiction. An assessment is made on the effectiveness of the Convention and its Committee in protecting the right to nationality.

\section{TABLE OF CONTENTS}

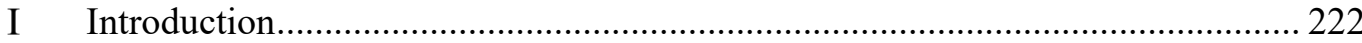

A Statelessness and Discrimination......................................................... 222

B The Content of the Convention ............................................................. 225

1 Grounds of Protection ................................................................. 226

2 Article 1(3) on Nationality and the Domaine Réservé ................. 226

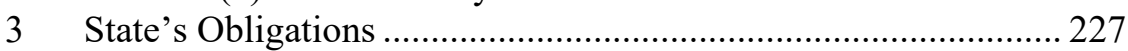

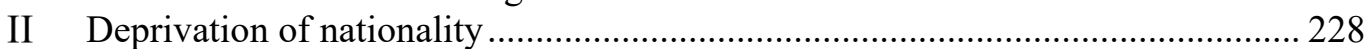

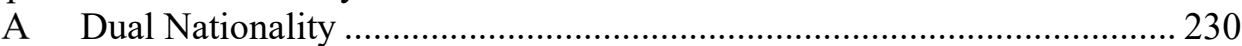

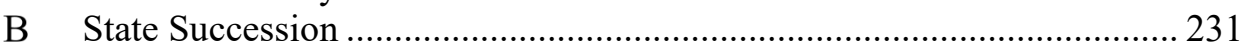

C Public Emergency and Terrorism ......................................................... 232

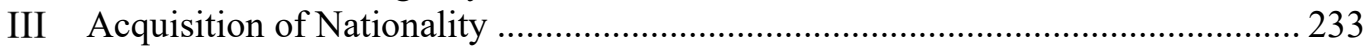

A Inclusion of Ethnicity in Nationality Laws........................................... 234

B Equal Access to Citizenship and Naturalisation....................................2236

C Public Authorities and Public Institutions ..............................................237

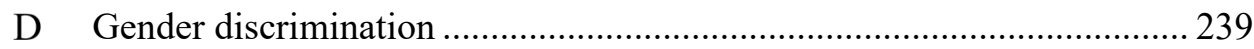

IV Positive Obligations to Eliminate Statelessness …….........................................240

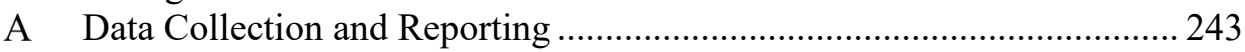

B Removal of Barriers to Naturalisation.................................................... 243

C Refugees and Displaced Persons ........................................................ 244

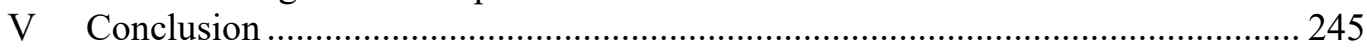

\section{INTRODUCTION}

Statelessness can have countless different root causes, and there are numerous ways in which a person can be deprived or denied of their citizenship — including

* Michiel Hoornick (LLM) is a researcher at the Leuven Centre for Global Governance Studies (KU Leuven), and after short stints with United Nations High Commissioner for Refugees ('UNHCR') and the Netherlands foreign service worked previously as a programme officer for the Institute on Statelessness and Inclusion. 
conflicts of domestic legislation, state succession and gender discriminatory legislation. However, discrimination and arbitrariness often play a key role. Such discrimination can be obvious and directly lead to statelessness, for example, when a state decides to deprive the citizenship of an entire ethnic group at once. It can also be a subtle element that nevertheless leaves a particular group more vulnerable to be left without citizenship, for example, when communities face extra administrative barriers or racism among officials. ${ }^{1}$ As a testament of such discrimination, the United Nations High Commissioner for Refugees ('UNHCR') estimates that approximately 75 per cent of the stateless individuals included in its statistics belong to a minority group. ${ }^{2}$

Article 5(d)(iii) of the International Convention on the Elimination of All Forms of Racial Discrimination ('ICERD') stipulates that

States Parties undertake to prohibit and to eliminate racial discrimination in all its forms and to guarantee the right of everyone ... to equality before the law, notably in the enjoyment of ... the right to nationality. ${ }^{3}$

Equality is treatment without any discrimination or distinction of any kind as to 'race, colour, descent, or national or ethnic origin'. ${ }^{4}$ As deprivation and denial of nationality on discriminatory grounds remain major causes of statelessness, $I C E R D$ has not lost its relevance regarding the right to nationality.

This paper is concerned with an assessment of the interpretation of the right to nationality by the Committee on the Elimination of Racial Discrimination ('the Committee'), the ICERD's monitoring body. An assessment of the Committee's approach on this matter reflects how the body is working towards fulfilling its promise of equal access to the right to a nationality as one of the rights listed in art 5 , and whether it is effective in doing so.

Naturally, the ICERD is not alone in this promise. The 1954 Convention Relating to the Status of Stateless Persons ('1954 Convention') and the 1961 Convention on the Reduction of Statelessness ('1961 Convention') ('Statelessness Conventions'), though not providing for a right to a nationality per se, set out a definition of statelessness, rules to ensure that stateless people enjoy a minimum set of human rights ${ }^{5}$ and how to prevent statelessness and reduce it over time through safeguards and concrete rules. ${ }^{6}$ The Statelessness Conventions are supplemented by a broad array of international and regional treaties that form a broad framework to protect against statelessness. Zooming in on the nine United Nations human rights conventions, each has its own scope and focus, and can be

1 Institute on Statelessness and Inclusion, The World's Stateless (Wolf Legal 2014) 23-27.

2 This is Our Home - Stateless Minorities and their Search for Citizenship (Report, UNHCR 2017) 1. By lack of an internationally agreed definition of a minority, the UNHCR describes a minority as 'an ethnic, religious or linguistic group, fewer in number than the rest of the population, whose members share a common identity'. Owing to this common identity that is different than the majority group, minorities in many situations face discrimination that could lead to statelessness.

3 International Convention on the Elimination of All Forms of Racial Discrimination (adopted 21 December 1965, entered into force 4 January 1969) UNGA Res. 2106 A (XX) ('ICERD') art 5(d)(iii).

4 ibid art 1.

5 Convention Relating to the Status of Stateless Persons, opened for signature 28 September 1954, 360 UNTS 117 (entered into force 6 June 1960) ('1954 Convention').

6 Convention on the Reduction of Statelessness, opened for signature 30 August 1961, 989 UNTS 185 (entered into force 13 December 1975) ('1961 Convention'). 
a tool to address particular root causes of statelessness. ${ }^{7}$ For example, art 9 of the Convention on the Elimination of All Forms of Discrimination against Women (' $C E D A W$ ') addresses gender discrimination in nationality laws, and art 7 of the Convention on the Rights of the Child (' $C R C$ ') provides for birth registration. Moreover, the ICERD, one of the first UN human rights conventions, owes its potential significance in the fight against statelessness to its mandate, which addresses one of the biggest root cause of statelessness - discrimination. ${ }^{8}$

Another great advantage of the ICERD is the number of its ratifications. ${ }^{9}$ As of 1 September 2020, the ICERD has 182 states parties, making it one of the most widely ratified human rights treaties. ${ }^{10}$ In comparison, there are 94 states parties to the 1954 Convention and 75 to the 1961 Convention. ${ }^{11}$ In total, over 95 per cent of the world's population are covered by the ICERD, including countries with substantial stateless populations not party to the Statelessness Conventions such as the Dominican Republic, Kenya, India and Thailand. ${ }^{12}$ This gives ICERD the potential of being a strong weapon for ensuring an effective nationality to all.

The Committee reviews 21-24 countries per year to give country-specific recommendations on the implementation of the ICERD in its so-called 'Concluding Observations'. As a result, 262 of such reviews, from the $65^{\text {th }}$ to the $100^{\text {th }}$ session, have taken place between the publication of General Recommendation No 30 on Discrimination against Non-Citizens ('GR 30') in 2004 and the submission of this paper. ${ }^{13}$ It would be worth noting at this point that there is a serious gap in reporting, with some countries having submitted zero reports to the Committee in this period, whereas others have written multiple. The voluntary nature of this reporting remains a challenge for indeed all treaty bodies.

7 Articles providing for (an equal enjoyment of) the right to a nationality include, but are not limited to: International Covenant on Civil and Political Rights, opened for signature 16 December 1966, 999 UNTS 171 (entered into force 23 March 1976) ('ICCPR') art 24; Convention on the Rights of the Child (adopted 20 November 1989, entry into force 2 September 1990) UNGA res 44/25 (' $C R C$ ') art 7; Convention on the Elimination of All Forms of Discrimination against Women, opened for signature 18 December 1979, 1249 UNTS 13 (entered into force 3 September 1981) ('CEDAW'); Convention on the Rights of Persons with Disabilities, GA Res 61/106, UN GAOR, 61 ${ }^{\text {st }}$ sess, Agenda Item 67(b), UN Doc A/RES/61/106 (24 January 2007, adopted 13 December 2006) ('CRPD') art 18; International Convention on the Protection of the Rights of All Migrant Workers and Members of Their Families, opened for signature 18 December 1990, 2220 UNTS 3 (entered into force 1 July 2003) art 29.

8 Amal de Chickera and Joanna Whiteman, 'Addressing Statelessness through the Rights to Equality and Non-Discrimination' in Laura van Waas and Melanie J Khanna (eds), Solving Statelessness (Wolf Legal 2016) 101.

9 Melanie J Khanna and Peggy Brett, 'Making Effective Use of UN Human Rights Mechanisms to Solve Statelessness' in Laura van Waas and Melanie J Khanna (eds), Solving Statelessness (Wolf Legal 2016) 35.

10 For the status of ratification of the $\operatorname{ICERD}$ (n 3), as well as all other multilateral treaties deposited with the United Nations Secretary-General, see United Nations Treaty Collection (Web Page) <https://treaties.un.org/>.

111954 Convention (n 5); 1961 Convention (n 6).

12 David Keane and Annapurna Waughray, 'Introduction' in David Keane and Annapurna Waughray (eds), Fifty Years of the International Convention on the Elimination of All Forms of Racial Discrimination - A Living Instrument (Manchester University Press 2014) 7.

13 Committee on the Elimination of Racial Discrimination, General Recommendation 30 on Discrimination against Non-Citizens, UN Doc CERD/C/64/Misc.11/Rev.3 (12 March 2004) [13]-[17] ('GR 30'). All 'Concluding Observations' are made public via the Office of the United Nations High Commissioner for Human Rights Website. See 'Human Rights Bodies' UN Treaty Body Database $\quad$ (Web $<$ https://tbinternet.ohchr.org/_layouts/TreatyBodyExternal/TBSearch.aspx $>$. The $101^{\text {st }}$ session, scheduled for April-May 2020, was postponed due to COVID-19. 
Nevertheless, in the period of 2004-19, the Committee has referred to themes related to 'nationality', 'statelessness' or 'naturalisation' in at least 145 Concluding Observations - over half of all such assessments - ranging from recommendations to accede to the Statelessness Conventions; to provide data on naturalisation procedures; to change citizenship legislation; and consider granting nationality to particular stateless groups.

In 2004, the Committee clarified in its $G R 30$ how it interpreted the obligations under the Convention regarding non-citizens, in which it devoted a section on access to citizenship. ${ }^{14}$ This interpretation is the starting point of this paper. In particular, the article will look at three aspects of the right to a nationality; deprivation of nationality, denial of nationality and positive obligations to fulfil the right to a nationality.

\section{B The Content of the Convention}

In comparison to the other instruments of that period - the Universal Declaration of Human Rights ('UDHR'), ${ }^{15}$ the Charter of the United Nations, ${ }^{16}$ the International Covenant on Civil and Political Rights ('ICCPR') and the International Covenant on Economic, Social and Cultural Rights. ${ }^{17}$ - the ICERD provides for the equal enjoyment of existing rights regardless of racial background, rather than it stipulating new rights. ${ }^{18}$ As Thornberry notes, the genesis of the ICERD strives against 'unfair or unjust distinctions on defined grounds' that lead to an unequal enjoyment of the already accepted human rights. ${ }^{19}$ As such, it relies on the rights included in other treaties. However, in art 5, an open-ended list of rights is provided, including in the right to a nationality. ${ }^{20}$ This builds onto the key art 1, defining racial discrimination, and art 2, which sets out the measures a member state should take to eliminate such discrimination.

The ICERD has repeatedly been described as a 'living instrument', which should be read in light of both legal and practical circumstances. The Committee therefore holds the opinion that the ICERD 'must be interpreted and applied taking into account the circumstances of contemporary society', and this interpretation can therefore change over time and with context. ${ }^{21}$ One of the changes over time has been that, although the ICERD does not create new rights, the rights listed

14 GR 30, UN Doc CERD/C/64/Misc.11/Rev.3 (n 13) [13]-[17].

15 Universal Declaration of Human Rights, GA Res $217 \mathrm{~A}$ (III), UN GAOR, $3^{\text {rd }}$ sess, $183^{\text {rd }}$ plen $\mathrm{mtg}$, UN Doc A/810 (10 December 1948) ('UDHR').

16 Charter of the United Nations.

17 ICCPR (n 7); International Covenant on Economic, Social and Cultural Rights, opened for signature 16 December 1966, 993 UNTS 3 (entered into force 3 January 1976).

18 Egon Schwelb, 'The International Convention on the Elimination of all Forms of Racial Discrimination' (1966) 15(4) The International and Comparative Law Quarterly 1001-2.

19 Patrick Thornberry, The International Convention on the Elimination of All Forms of Racial Discrimination (Oxford University Press 2016) 132.

20 ICERD (n 3) art 5(d)(iii).

21 Thornberry (n 19) 4; Committee on the Elimination of Racial Discrimination, General Recommendation No 32: The Meaning and Scope of Special Measures in the International Convention on the Elimination of All Forms Racial Discrimination, UN Doc CERD/C/GC/32 (24 September 2009) ('GR 32') [5]; Committee on the Elimination of Racial Discrimination, Communication No 26/2002, UN Doc CERD/C/62/D/26/2002 (14 April 2003) [7.3]; Committee on the Elimination of Racial Discrimination, General Recommendation 35 on Combatting Racist Hate Speech, UN Doc CERD/C/GC/35 (26 September 2013) [4]. 
under art 5 have become so fundamental that they are, in practice, being regarded as normative standards on their own. ${ }^{22}$

\section{Grounds of Protection}

The grounds on which states should not discriminate under the ICERD are identified in art 1(1) as 'race, colour, descent or national or ethnic origin'. These grounds are all grouped under the umbrella term 'racial discrimination', although in practice, the Committee does not always state clearly on which particular ground it deems a certain practice or policy discriminatory. ${ }^{23}$ These grounds are not limited to race or ethnicity alone, but extend to a broader notion of background. ${ }^{24}$ For instance, the Committee has specifically mentioned the link between racial discrimination and discrimination based on religion, ${ }^{25}$ and has emphasised that states should pay particular attention to possible 'complex forms of disadvantage', when racial discrimination is combined with other grounds not necessarily covered by the ICERD, such as sex and gender. ${ }^{26}$ This is particularly relevant for statelessness, which is more often than not grounded in a mix of various causes. For instance, women from minority groups could experience double discrimination, and be more vulnerable to nationality issues.

In art 5, a listing of protected grounds similar to the one in art 1 is provided. Worth noting is the absence of 'descent' as one of the grounds in which states ought not discriminate. While absent in this article, the Committee made clear in its General Recommendation No 29 that it considers it a protected ground on par with 'race, colour, or national or ethnic origin', and that in this also includes 'social stratifications' such as caste, other 'analogous systems of inherited status', and religion. ${ }^{27}$

\section{Article 1(3) on Nationality and the Domaine Réservé}

From the outset, the right to nationality was not undisputed. Article 1(3) stipulates that 'legal provisions of States Parties concerning nationality, citizenship or naturalization' fall within the reserved domain of sovereign states, however 'provided that such provisions do not discriminate against any particular nationality'. ${ }^{28}$ The right to nationality was not extensively discussed in the preparatory works and was initially intended, as argued by Egon Schwelb, only to

22 Thornberry (n 19) 393.

23 Keane and Waughray (n 12) 8.

24 Thornberry (n 19) 119-20, 136.

25 Committee on the Elimination of Racial Discrimination, Guidelines for the CERD-Specific Document to be Submitted by State Parties under Article 9, Paragraph 1, of the Convention, UN Doc CERD/C/2007/1 (13 June 2008) ('SRG') [19] art 5(I)(D)(7).

26 ibid [19] art 5(II)(B). See also Committee on the Elimination of Racial Discrimination, General Recommendation No 25: Gender-Related Dimensions of Racial Discrimination, UN Doc CERD/C/GC/25 (20 March 2000) [3] ('GR 25').

27 Committee on the Elimination of Racial Discrimination, General Recommendation No 29 on article 1, paragraph 1, of the Convention (Descent), UN Doc A57/18 (1 November 2002) preamble [aa]-[vv].

28 ICERD (n 3) art (1)(3) reads that:

Nothing in this Convention may be interpreted as affecting in any way the legal provisions of States Parties concerning nationality, citizenship or naturalization, provided that such provisions do not discriminate against any particular nationality. 
protect against deprivation of nationality. ${ }^{29}$ Increasingly, this interpretation has changed, and state sovereignty regarding nationality, citizenship or naturalisation has become more regulated by the ICERD, as well as other conventions. ${ }^{30}$ More recent scholars also link 'discrimination against any particular nationality' with ethnic origin. ${ }^{31}$ According to Patrick Thornberry, 'nationality' in this sense of the word could refer not only to 'legal citizenship', but also to a deeper concept of 'community', including ethnicity. ${ }^{32} \mathrm{He}$ concludes that practice has shown that art 1(3) does not allow for discrimination on any of the grounds identified in art 1(1) with regards to the right to nationality under art 5(d)(iii). ${ }^{33}$

On 8 March 2018, Qatar submitted two inter-state communications before the Committee against Saudi Arabia and the United Arab Emirates ('UAE'), arguing that these two Member States 'enacted and implemented discriminatory policies directed at Qatari citizens', including expulsion and other human rights violations. ${ }^{34}$ In both cases, the Committee dismissed responses by the respondent states "related to the absence of "nationality" in the definition of racial discrimination prohibited by the Convention'. ${ }^{35}$ A parallel case between Qatar and $\mathrm{UAE}$ on a possible violation of the ICERD is currently before the International Court of Justice. ${ }^{36}$

\section{State's Obligations}

The State's obligations to eliminate racial discrimination are outlined under art 2 of the ICERD. In principle, state parties have to pursue 'by all appropriate means' a policy of eliminating racial discrimination. This includes obligations to respect, such as 'to engage in no act or practice of racial discrimination' and 'not to sponsor, defend or support racial discrimination'. ${ }^{37}$ Further, states are obliged to protect, such as by 'ensuring that all public authorities and public institutions' do not engage in acts or practices of racial discrimination and 'prohibit and bring to an end ... racial discriminations by any persons, group or organisation'. Last, states have to fulfil, most notably by taking 'special and concrete measures'. ${ }^{38}$ In

29 Schwelb (n 18) 1008.

30 Thornberry (n 19) 125.

31 Natan Lerner, The UN Convention on the Elimination of All Forms of Racial Discrimination (Sijthoff \& Noordhoff 1980) 30; Ion Diaconu, Racial Discrimination (Eleven International Publishing 2012) 152.

32 Thornberry (n 19) 125.

33 ibid 88, 146, 157-58; See also GR 30, UN Doc CERD/C/64/Misc.11/Rev.3 (n 13) [2].

34 Committee on the Elimination of Racial Discrimination, Jurisdiction of the Inter-State Communication Submitted by Qatar against the Kingdom of Saudi Arabia, UN Doc CERD/C/99/5 (30 August 2019) [6]; Committee on the Elimination of Racial Discrimination, Admissibility of the Inter-State Communication Submitted by Qatar against the Kingdom of Saudi Arabia, UN Doc CERD/C/99/6 (30 August 2019); Committee on the Elimination of Racial Discrimination, Jurisdiction of the Inter-State Communication Submitted by Qatar against the United Arab Emirates, UN Doc CERD/C/99/3 (30 August 2019) [6]; Committee on the Elimination of Racial Discrimination, Decision on the Admissibility of the Inter-State Communication Submitted by Qatar against the United Arab Emirates, UN Doc CERD/C/99/4 (27 August 2019) ('Qatar v UAE').

35 Qatar $v$ UAE, UN Doc CERD/C/99/4 (n 34) [63].

36 For the latest developments, see 'Application of the International Convention on the Elimination of All Forms of Racial Discrimination (Qatar v United Arab Emirates)' International Court of Justice (Web Page) <https:/www.icj-cij.org/en/case/172>.

$37 \operatorname{ICERD~(n~3)~art~} 2$.

38 GR 32, UN Doc CERD/C/GC/32 (n 21). 
the following sections, we will look at where the Committee stands regarding each of these obligations in relation to the right to a nationality.

\section{DEPRIVATION OF NATIONALITY}

The most aggressive violation of the right to nationality is its deprivation; when a person once had a particular citizenship that has since been unlawfully taken away. Such violations can include both individual as well as collective denationalisation of a particular group, often for purely discriminatory reasons. ${ }^{39}$ In the worst cases, this can be done by directly stripping nationality solely because of the race or ethnicity a person belongs to and could be one step in a pattern of stigmatisation, xenophobia and displacement. For example, the scenario we have seen unfold in, among others, Myanmar. ${ }^{40}$ The Committee has already clarified that deprivation of citizenship on discriminatory grounds is a breach of ICERD.$^{41}$ It recognises that ethnic differences are often exploited for political gain and that citizenship can and has been used for political purposes and nationalism, leading to detrimental effects upon those whose nationality has been deprived. ${ }^{42}$

Looking at international human rights law more widely, the $U D H R$ states that 'no one shall be arbitrarily deprived of his nationality', and the $C R C$ obliges states to 'undertake to respect the right of the child to preserve his or her identify, including nationality'. 43 'Arbitrary', under international law, does not necessarily equal 'against the law', but 'constitutes broadly to include elements of inappropriateness, injustice, lack of predictability and due process of law', ${ }^{44}$ Furthermore, the 1961 Convention stipulates that states 'may not deprive any person or group of persons of their nationality on racial, ethnic, religious or political grounds' or, more generally, 'if such deprivation would render him stateless'. 45

The 1961 Convention does allow for revocation of nationality in a number of rare circumstances, such as 'where the nationality has been obtained by misrepresentation or fraud' under its art $8(2)(\mathrm{b})$ or if the person's behaviour has been 'inconsistent with his duty of loyalty to the [state]' under art 8(3). ${ }^{46}$ However, the use of revocation of citizenship for reasons related to national security should be seen as a narrow exception to the prohibition of deprivation of nationality and is subject to high standards of international law, including non-discrimination and a general prohibition of statelessness. Moreover, it has been recognised that

39 Institute of Statelessness and Inclusion (n 1) 25.

40 ibid 32-35.

41 GR 30, UN Doc CERD/C/64/Misc.11/Rev.3 (n 13) [14].

42 Committee on the Elimination of Racial Discrimination, General Recommendation 15 : Organized Violence Based on Ethnic Origin (Art 4), UN Doc A/48/18 (23 March 1993).

$43 U D H R(\mathrm{n} 7)$ art 15; CRC (n 7) art 8.

44 On the notion of 'arbitrariness', see, eg, United Nations Human Rights Council, Report of the Working Group on Arbitrary Detention, UN Doc A/HRC/22/44 (24 December 2012) [61]. For arbitrary deprivation of citizenship specifically, see United Nations Human Rights Council, Human Rights and Arbitrary Deprivation of Nationality: Report of the Secretary General, UN A/HRC/25/28 (19 December 2013) [4].

451961 Convention (n 6) arts 8(1), 9.

46 ibid arts $3,5,7(4), 8(2 \mathrm{~b})$. 
citizenship deprivation might result in human rights violations that are, even in a time of emergency, non-derogable. ${ }^{47}$

The Committee confirmed in $G R 30$ that the right to nationality under art 5(d)(iii) of the ICERD includes a prohibition upon the deprivation of nationality, 'recogniz[ing] that deprivation of citizenship on the basis of race, colour, descent, or national or ethnic origin is a breach of State Parties' obligations to ensure nondiscriminatory enjoyment of the right to nationality'. ${ }^{48}$ Also in its Concluding Observations, the Committee has repeatedly stressed that 'deprivation of citizenship on the basis of national or ethnic origin is a breach of the obligation to ensure non-discriminatory enjoyment of the right to nationality' ${ }^{49}$ Among others, the Concluding Observations on Jordan show how the Committee phrases its recommendations regarding deprivation of nationality. After Jordan withdrew the nationality of citizens from Palestinian origin, 50 the Committee condemned this in 2012 and 2017 and urged Jordan to 'put an end to the withdrawal of nationality from persons from the Occupied Palestinian Territory and restore the nationality of those who have been affected by that practice'. 51

The Committee has acknowledged the possible consequences of (mass) denationalisation, and noted that deprivation of nationality could lead to the expulsion of the group affected. For example, in April 1989, after a number of years of polarisation and Arab nationalism, the Mauritanian government started to denationalise and consequently expel its population of black African descent, mainly to Senegal. ${ }^{52}$ In its Concluding Observations of Mauritania's reports in 2004 and 2018, the Committee recommended to encourage the return of these refugees, to take measures for reintegration into Mauritanian society, and stated

47 For a more elaborate overview of the current status quo on deprivation of nationality as a national security measure, see: Draft Commentary to the Principles on Deprivation of Nationality as a National Security Measure (Commentary, Institute on Statelessness and

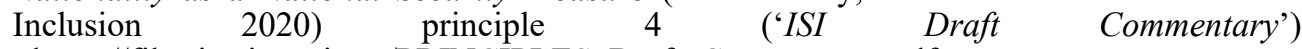
$<$ https://files.institutesi.org/PRINCIPLES_Draft_Commentary.pdf > .

48 GR 30, UN Doc CERD/C/64/Misc.11/Rev.3 (n 13) [14].

49 Committee on the Elimination of Racial Discrimination, Consideration of Reports submitted by State Parties under Article 9 of the Convention: Concluding Observations of the Committee on the Elimination of Racial Discrimination: Lithuania:, UN Doc CERD/C/LTU/CO/3 (11 April 2006) [23] ('Concluding Observations: Lithuania'); Committee on the Elimination of Racial Discrimination, Concluding Observations of the Committee on the Elimination of Racial Discrimination, Consideration of Reports Submitted by State Parties under Article 9 of the Convention: Concluding Observations of the Committee on the Elimination of Racial Discrimination : Turkmenistan, UN Doc CERD/C/TKM/CO/5 (27 March 2007) [16] ('Concluding Observations: Turkmenistan').

50 Stateless Again: Palestinian-Origin Jordanians Deprived of their Nationality (Report, Human Rights Watch 2 February 2010) < https://www.refworld.org/docid/4b6ae5702.html $>4$.

51 Committee on the Elimination of Racial Discrimination, Consideration of Reports Submitted by States Parties under Article 9 of the Convention: Concluding Observations of the Committee on the Elimination of Racial Discrimination: Jordan, UN Doc CERD/C/JOR/CO/13-17 (4 April 2012) [12]-[13]; Committee on the Elimination of Racial Discrimination, Concluding Observations on the Combined Eighteenth to Twentieth Periodic Reports of Jordan, UN Doc CERD/C/JOR/CO/18-20 (26 December 2017) [14]-[15] ('Concluding Observations: Jordan').

52 Institute of Statelessness and Inclusion (n 1) 111-12; 'Statelessness in Mauritania: A Brief Account of a Long History of Discrimination', The Legal Agenda (Web Page, 19 January 2016) $<$ http://legal-agenda.com/en/article.php?id=744\&folder=articles\&lang=en $>$. 
its concern over the risk of statelessness amongst these returnees. ${ }^{53}$ On the situation in the Dominican Republic, the Committee strongly condemned the retro-active application of its General Law on Migration No 285-04, through which persons of Haitian descent were stripped of their Dominican nationality. ${ }^{54}$ Furthermore, it expressed its concern of the broader consequences that this deprivation of nationality can have, particularly when it comes to 'mass, indiscriminate and arbitrary deportations of citizens of Haitian origin'.55

\section{A Dual Nationality}

Similar to what is written in the 1961 Convention, the Committee has indicated that the loss of nationality with the acquisition of another is not necessarily deprivation of nationality as a violation of art 5(d)(iii) of the ICERD, as long as it is not discriminatory. Referring directly to $G R 30$, the Committee did raise its concern over a provision in the Lithuanian Law on Citizenship, which at the time stipulated that only citizens of Lithuanian origin were allowed to be a dual national, a measure taken to prevent the ethnic Russian population that arrived after 1940 from acquiring Lithuanian citizenship as their second. ${ }^{56}$ Citizens of non-Lithuanian origin lost their citizenship upon acquisition of another nationality. ${ }^{57}$ The Committee stressed that 'deprivation of citizenship on the basis of national or ethnic origin is a breach of the obligation to ensure nondiscriminatory enjoyment of the right to nationality' and urged Lithuania 'to refrain from adopting any policy that directly or indirectly leads to such deprivation'. 58

Deprivation of nationality falls under the mandate of the ICERD if it is discriminatory, based on the race, colour, descent, or national or ethnic origin of the person whose citizenship has been revoked. This is first of all reiterated in the Committee's GR 30, which states that 'deprivation of citizenship on the [protected grounds] is a breach of States parties' obligations to ensure non-discriminatory enjoyment of the right to nationality. ${ }^{59}$ Furthermore, the Committee has raised its concern during the periodic report of Togo, which requires applicants for citizenship to first relinquish the nationality of origin before granting Togolese

53 Committee on the Elimination of Racial Discrimination, Consideration of Reports Submitted by States Parties under Article 9 of the Convention: Concluding Observations of the Committee on the Elimination of Racial Discrimination: Mauritania, UN Doc CERD/C/65/CO/5 (10 December 2004) [17]; Committee on the Elimination of Racial Discrimination, Concluding Observations on the Combined Eight to Fourteenth Reports of Mauritania, UN Doc CERD/C/MRT/CO/8-14 (30 May 2018) [23]-[24].

54 General Law on Migration No 285-04 (2004) (Dominican Republic); Institute of Statelessness and Inclusion (n 1) 8-10.

55 Committee on the Elimination of Racial Discrimination, Concluding Observations on the Thirteenth and Fourteenth Periodic Reports of the Dominican Republic, Adopted by the Committee in its Eighty-Second Session (11 February - 1 March 2012), UN Doc CERD/C/DOM/CO/13-14 (19 April 2013) [18]-[21].

56 Law of the Republic of Lithuania on Citizenship (2002) Law No IX-1078 (Republic of Lithuania) arts $18(1)(2)$.

57 ibid art 18(2).

58 Concluding Observations: Lithuania, UN Doc CERD/C/LTU/CO/3 (n 49) [23]; Committee on the Elimination of Racial Discrimination, Concluding Observations on the Combined Ninth and Tenth Periodic Reports: Lithuania, UN Doc CERD/C/LTU/CO/9-10 (7 June 2019); Law of the Republic of Lithuania on Amending Articles 1, 17 and 28 of the Law of the Republic of Lithuania on Citizenship (1991) Law No VIII-391 (Republic of Lithuania) art 18(1).

GR 30, UN Doc CERD/C/64/Misc.11/Rev.3 (n 13) [14]. 
nationality. ${ }^{60}$ While this practice does not discriminate on the background of the applicant, the person could be left in limbo if his or her Togolese citizenship application gets denied. In such cases, the state party is expected to provide for a legal safeguard. Similarly, the Committee recommended Uzbekistan

to adopt urgent measures to remove obstacles to granting citizenship and prevent persons from becoming stateless, in particular in the process of acquiring citizenship of the State party. ${ }^{61}$

\section{B State Succession}

Equal application of citizenship legislation without discrimination on race or other grounds under art 1(1) is particularly relevant in the context of state succession. When a country splits up or an area gains independence, the new-born state or states must define themselves and their population. With the new definition of what constitutes as the state, minorities are particularly vulnerable where their heritage is associated with the parent or successor state, leaving them at risk of being deprived of nationality. ${ }^{62}$ The Committee made reference to this specific issue in GR 30 and advised states to 'regularise the status of former citizens of predecessor States who now reside within the jurisdiction of the State Party'. ${ }^{63}$

In its Concluding Observations, the Committee condemned the 2011 amendment to the Sudanese Nationality Act 1994, which 'provides for the revocation of the Sudanese nationality of those who have acquired "de jure or de facto" the nationality of South Sudan'. ${ }^{64}$ According to the Committee, this amendment could give rise to situations in which the Sudanese government strips the citizenship of persons belonging to an ethnic group associated with South Sudan, rendering them at risk of statelessness. Therefore, the Committee recommended Sudan to 'ensure that rules governing citizenship acquisition and deprivation apply equally to all without discrimination based on, inter alia, ethnicity and protect against statelessness'. ${ }^{65}$ The Committee raised similar concerns on the 'Erased' persons (Izbrisani) in Slovenia, a group that remained without a legal status after the declaration of the country's independence in 1991 and is mostly of non-Slovene or mixed ethnicity and includes a significant number

60 Committee on the Elimination of Racial Discrimination, Concluding Observations on the Combined Eighteenth and Nineteenth Periodic Reports of Togo, UN Doc CERD/C/TGO/CO/18-19 (18 January 2017) [27] ('Concluding Observations: Togo'), citing Code de la nationalité Togolaise [Code of Togolese Nationality] (1978) Ordinance No 78-34 (Republic of Togo).

61 Committee on the Elimination of Racial Discrimination, Concluding Observations on the Combined Tenth to Twelfth Reports of Uzbekistan, UN Doc CERD/C/UZB/CO/10-12 (27 January 2020) [21].

62 Institute of Statelessness and Inclusion (n 1) 25.

63 GR 30, UN Doc CERD/C/64/Misc.11/Rev.3 (n 13) [17].

64 Sudanese Nationality Act (Amendment) 2011 (Sudan) s 10(2). According to UNHCR, 'the [Sudanese] decision to revoke nationality from any individual qualifying for South Sudanese nationality has left many people at risk of statelessness'. Additional difficulties that lead to the risk of statelessness are administrative challenges, lack of capacity and discrimination among public authorities, economic barriers and displacement. See A Study of Statelessness in South Sudan (Study, UNHCR 2017) 30.

65 Committee on the Elimination of Racial Discrimination, Concluding Observations on the Combined Twelfth to Sixteenth Periodic Reports of the Sudan, $86^{\text {th }}$ sess, UN Doc CERD/C/SDN/CO/12-16 (12 June 2015) [19]. 
of members from Romani communities. ${ }^{66}$ It recommended in a similar manner on the acquisition of citizenship of former Soviet citizens in the Russian Federation, Kyrgyzstan and Georgia, many of whom were rendered stateless after the dissolution of the Soviet Union. ${ }^{67}$

\section{Public Emergency and Terrorism}

In recent years there has been a trend among a small but growing group of states to use revocation of citizenship as a counter-terrorism measure, either based on existing laws or through new legislation. ${ }^{68}$ On the relation between such measures and human rights obligations, art 4(1) of the ICCPR prescribes that 'in time of public emergency ... States Parties ... may take measures derogating from their obligations under the present Covenant'. Such emergency could be a legitimate justification for states to limit certain rights when facing a serious threat, provided that it does not result in 'discrimination on the ground of race, colour, sex, language, religion or social origin'. ${ }^{69}$ The 1961 Convention stipulates that 'inconsisten[cy] with [someone's] duty of loyalty to the [state]' could be a justification for revocation of nationality. ${ }^{70}$ However, it should be noted that the threshold for such a justification is very high, subject to the necessary procedural safeguards and other principles. ${ }^{71}$

On national security in this context, the Committee suggest that states 'ensure that measures taken in the fight against terrorism do not discriminate' and that 'non-citizens detained or arrested in the fight against terrorism are properly protected'. ${ }^{72}$ If one of the measures taken by the state includes to revoke the nationality of a suspect of terrorism on the basis of one of the protected grounds under art 1(1), this measure is a potential violation of art 5(d)(iii), especially if it leads to statelessness. The Committee raised its concern on Qatar, stating that 'reported cases of citizens being deprived of citizenship in the State party, which

66 Committee on the Elimination of Racial Discrimination, Concluding Observations on the Combined Eighth to Eleventh Periodic Reports of Slovenia, $88^{\text {th }}$ sess, UN Doc CERD/C/SVN/CO/8-11 (11 January 2016) [12]-[13].

67 Committee on the Elimination of Racial Discrimination, Consideration of the Reports Submitted by States Parties under Article 9 of the Convention: Concluding Observations of the Committee on the Elimination of Racial Discrimination: Russian Federation, UN Doc CERD/C/RUS/CO/19 (22 September 2008) [23]; Committee on the Elimination of Racial Discrimination, Consideration of the Reports, Comments and Information Submitted by States Parties under Article 9 of the Convention: Concluding Observations in the Fifth to Seventh Periodic Reports of Kyrgyzstan, UN Doc CERD/C/KGZ/CO/5-7 (1 March 2013) [17]; Committee on the Elimination of Racial Discrimination, Consideration of Reports Submitted by States Parties under Article 9 of the Convention: Concluding Observations of the Committee on the Elimination of Racial Discrimination: Georgia, UN Doc CERD/C/GEO/CO/4-5 (20 September 2011) [3].

68 ISI Draft Commentary (n 47) 5-6.

$69 \operatorname{ICCPR}(\mathrm{n} 7)$ art 1. See also Committee on Civil and Political Rights, General Comment No 29: Article 4: Derogations during a State of Emergency, UN Doc CCPR/C/21/Rev.1/Add.11 (31 August 2001). Moreover, there are a number of rights in the ICCPR (n 7) that are 'nonderogable' and that may under no circumstances be limited upon, such as the right to life (art 6 ), the right to prohibition against the retrospective operation of criminal laws (art 15) and the right to recognition before the law (art 16).

$70 \quad 1961$ Convention art 8(3)(a).

71 United Nations High Commissioner for Refugees, Guidelines on Statelessness No 5: Loss and Deprivation of Nationality under Articles 5-9 of the 1961 Convention on the Reduction of Statelessness, UN Doc HCR/GS/20/05 (May 2020) [64], [66]. See also ISI Draft Commentary (n 47) [75].

72 GR 30, UN Doc CERD/C/64/Misc.11/Rev.3 (n 13) [10], [20]. 
may lead to a risk of statelessness', however, did not mention its context. ${ }^{73}$ The Committee has not referred to the right to nationality specifically in relation to the fight against terrorism in recent communications. The Committee raised its concern during Kenya's Concluding Observations about 'reports that counterterrorism initiatives to combat the Somali militant group Al-Shabab, including ethnic profiling of certain ethnic groups, have resulted in human rights violations' ${ }^{74}$ This would suggest that, as long as counter-terrorism measures are applied without discrimination, this would not fall under the mandate of the Committee.

Following $G R$ 30, the Committee has repeatedly made clear that arbitrary deprivation of nationality is a breach of the ICERD and has consistently applied this by condemning deprivation of nationality. Yet, states can revoke citizenship on an individual basis if that revocation is not discriminatory. States that automatically revoke a person's citizenship when that person acquires a second nationality, provided that this is not done on a discriminatory basis and that the person can effectively enjoy his or her 'new' nationality, are not in violation of the ICERD. Although the Committee has not specifically referred to the need for safeguards to prevent statelessness, the line between compliance and violation of art 5(d)(iii) is drawn very clearly at the equal application of such practices. States have an obligation to ensure that there is no discriminatory agenda behind revocation of nationality, when it is done for an otherwise legitimate reason. ${ }^{75}$

\section{ACQUISITION OF NATIONALITY}

As with deprivation of nationality, political and discriminatory motivations can play a big part in access to citizenship and naturalisation. ${ }^{76}$ In some cases, discrimination can be direct, when states - trying to build a national identity partially or fully based on a particular ethnicity - include ethnicity in their citizenship legislation. In other cases, public authorities and civil servants could hold personal prejudices where it is not official state policy or legislation to discriminate on race or ethnicity. This Part will provide an analysis of what the Committee has said regarding discrimination related to access to citizenship or naturalisation, but will also look at the role of gender discrimination. As previously mentioned, the Committee does not look at racial discrimination in isolation, but looks more broadly at the intersections with other groups. This is most explicitly so for the intersection with gender discrimination. In 2000, it adopted a General Recommendation on the role of gender in racial discrimination and also in later documents, it emphasised the importance of this role. ${ }^{77}$

Further than the general right to nationality under art 15 of the $U D H R$, a number of international human rights instruments include provisions specifically for the

73 Committee on the Elimination of Racial Discrimination, Concluding Observations on the Combined Seventeenth to Twenty-First Periodic Reports of Qatar, UN Doc CERD/C/QAT/CO/17-21 (2 January 2019) [27]-[28].

74 Committee on the Elimination of Racial Discrimination, Concluding Observations on the Fifth to Seventh Period Reports of Kenya, UN Doc CERD/C/KEN/CO/5-7 (8 June 2017) [29] ('Concluding Observations: Kenya').

75 Committee on the Elimination of Racial Discrimination, Habassi v Denmark: Opinion, UN Doc CERD/C/54/D/10/1997 (6 April 1999) [9.3].

76 Laura van Waas, Nationality Matters (Intersentia, Human Rights Research Series 2008) vol 29,360 .

77 GR 25, UN Doc CERD/C/GC/25 (n 26). 
acquisition of nationality. ${ }^{78}$ The UN Human Rights Committee ('HRC') has stated in its General Comment No 17 that states do not necessarily have an obligation to 'give their nationality to every child born in their territory'. ${ }^{79}$ This does not, however, omit that there are certain limits on the freedom of states in prescribing their citizenship requirements. ${ }^{80}$ In this light, it has been increasingly acknowledged that, in many cases, statelessness as the result of the denial of nationality may be arbitrary under international law. ${ }^{81}$ Also, the 1961 Convention offers safeguards against statelessness at birth and contracting states 'shall grant its nationality to a person born in its territory who would otherwise be stateless'. It also protects persons at risk of becoming stateless if that statelessness would be caused by conflict of nationality legislation. ${ }^{82}$

Considering the international character of the right to nationality, it is in many cases not clear which state is responsible for the acquisition of nationality of an individual. In preparation to the adoption of $G R 30$ on the rights of non-citizens, the former Special Rapporteur on the Rights of Non-Citizens emphasised, however, that states parties ought to treat all non-citizens equally, including when it comes to acquisition of nationality. ${ }^{83}$ This was reaffirmed by the Committee, recommending that states 'ensure that particular groups of non-citizens are not discriminated against with regard to access to citizenship or naturalization'. 84 While deprivation of nationality on the basis of race or descent 'is a breach of the Convention', the Committee has chosen slightly softer wording on denial of nationality and recommended that states 'take into consideration that ... denial of citizenship ... could result in the creation of disadvantage ... in terms of access to employment and social benefits' ${ }^{85}$ The Committee, in its General Recommendation No 34 on persons of African descent, repeats this wording and reiterates that states have an obligations to 'ensure that legislation regarding citizenship and naturalization does not discriminate against people of African descent'. ${ }^{86}$

\section{A Inclusion of Ethnicity in Nationality Laws}

The most direct form of denial of nationality on a discriminatory basis is excluding particular groups from their nationality legislation. This is a particularly relevant reasoning in former colonised or newly established states, which were or are still in the process of nation-building. ${ }^{87}$ However, the inclusion of certain racial or

$78 \operatorname{ICCPR}(\mathrm{n} 7)$ art 24; CRC (n 7) art 7(1); CEDAW (n 7) art 9(1); CRPD (n 7) art 18(a).

79 United Nations Human Rights Committee, CCPR General Comment No 17: Article 24 (Rights of the Child), UN Doc HRI/GEN/1/Rev.9 (7 April 1989) ('GC 17') [8].

$80 \quad$ Van Waas (n 76) 97.

81 De Chickera and Whiteman (n 8) 101.

821961 Convention (n 6) arts 1, 4; Van Waas (n 76) 54.

83 United Nations Sub-Commission on the Promotion and Protection of Human Rights, The Rights of Non-Citizens: Final Report of the Special Rapporteur, Mr David Weissbrodt, Submitted in Accordance with Sub-Commission Decision 2000/103, Commission Resolution 2000/104 and Economic and Social Council Decision 2000/283, UN Doc E/CN.4/Sub.2/2003/23 (26 May 2003) [20]-[21].

84 GR 30, UN Doc CERD/C/64/Misc.11/Rev.3 (n 13) [13].

85 ibid [15].

86 Committee on the Elimination of Racial Discrimination, General Recommendation No 34 Adopted by the Committee: Racial Discrimination against People of African Descent, UN Doc CERD/C/GC/34 (3 October 2011) ('GR 34') [48]-[49].

87 Thornberry (n 19) 3. 
ethnic groups in national legislation could lead to the direct or indirect exclusion of other groups not included in those laws. Liberia, founded by former AfroAmerican slaves from the United States, is perhaps the clearest example. Its 1986 Constitution of the Republic of Liberia stipulates that only those of 'negro descent' are eligible for citizenship, 'in order to preserve, foster and maintain the positive Liberian culture, values and character'. ${ }^{88}$ Similar sentiments can be found in Sierra Leone and in the Democratic Republic of Congo ('DRC'). ${ }^{89}$ The Committee did not make a comment on Liberia's latest Concluding Observations in 2001 and only noted in 1996 that Sierra Leone's Citizenship Act of 1973 differentiated on race. ${ }^{90}$ On the $D R C$, the Committee recommended in 2007 to 'ensure that the application [of its nationality legislation does] not give rise to discrimination in the enjoyment of the right to nationality by members of certain ethnic groups residing within its territory'. ${ }^{91}$ As a testament to the lack of reporting by a large number of states and a reflection of one of the major weaknesses of UN treaty bodies generally, all three have not submitted a report to the Committee since.

The inclusion of ethnicity might also be relevant for states with a sizable diaspora, who wish to maintain or strengthen the (ethnic) connection with its population. For example, Israel's 1950 Law of Return gives every Jewish person the 'right to return' and upon arrival, become an Israeli national under the 1952 Nationality Law. ${ }^{92}$ A similar provision can be found in Ghana, which provides for a 'right to abode' to persons of African descent. ${ }^{93}$ The Law of 1995 on Citizenship of the Republic of Armenia provides for a simplified procedure to become citizens for ethnic Armenians. ${ }^{94}$ This aspect was not raised in recent Concluding Observations of Ghana, nor Armenia. However on Israel, the Committee recommended that Israel 'ensure that the definition of Israel as a Jewish nation State does not result, in any systemic distinction, exclusion, restriction or preference based on race, colour, descent, or national or ethnic origin in the enjoyment of human rights'; repeatedly recommended that Israel reconsidered its policy on citizenship and residence permits through family reunification so that it

881986 Constitution of the Republic of Liberia (Liberia) art 27.

89 Citizenship Act of 1973 (Sierra Leone) ('Sierra Leone Citizenship Act'), as amended by Sierra Leone Citizenship (Amendment) Act, 2006, Act No 11 of 2006 (Sierra Leone); Citizenship (Amendment) Act, Act No 33 of 2017 (Sierra Leone). See also 'Causes of Minority Statelessness', Minority Stories (Web Page, 2017) $<\mathrm{http}$ ://stories.minorityrights.org/statelessness/chapter/causes-of-statelessness/>.

90 Committee on the Elimination of Racial Discrimination, Report of the Committee on the Elimination of Racial Discrimination: Concluding Observations: Liberia, UN Doc A/56/18; Committee on the Elimination of Racial Discrimination, Report of the Committee on the Elimination of Racial Discrimination: Concluding Observations: Sierra Leone, A/50/18(SUPP) [589], citing Sierra Leone Citizenship Act (n 89). Note, both reviews were conducted before the Committee's GR 30 in 2004: GR 30, UN Doc CERD/C/64/Misc.11/Rev.3 (n 13).

91 Committee on the Elimination of Racial Discrimination, Report of the Committee on the Elimination of Racial Discrimination: Concluding Observations: Democratic Republic of the Congo, UN Doc A/62/18 (17 August 2007) [331] ('Concluding Observations: DRC').

92 Law of Return (1950) Law No 5710-1950 (Israel); Nationality Law (1952) Law No 57121952 (Israel).

93 Immigration Act, Act No 573 of 2000 (Ghana) s 17(1)(b).

94 Law of 1995 on Citizenship of the Republic of Armenia (Armenia) art 1. 
happens on a non-discriminatory basis; and that the restrictions to it are 'necessary and limited in scope' .95

\section{B Equal Access to Citizenship and Naturalisation}

Equally important to the question of whether citizenship legislation could include ethnic elements is the manner in which these laws are applied. Vague standards, arbitrary application of procedures related to acquisition of nationality or discriminating procedural requirements, can prevent individuals from access to citizenship or naturalisation, despite fulfilling the criteria set out in the respective citizenship laws to become a citizen. In its Guidelines for the CERD-Specific Document to be Submitted by State Parties under Article 9, Paragraph 1, of the Convention (' $S R G$ '), the Committee is clear and requests information on 'measures taken to ensure that particular groups of non-citizens are not discriminated against with regard to access to citizenship or naturalization'. ${ }^{96}$

The Committee recommended Cambodia to take measures to ensure identification documents recognising their citizenship are provided to Khmer Krom - an ethnic minority often associated with neighbouring Vietnam and, further, to allow individuals belonging to this group to record their true name and place of birth in their identification documents. ${ }^{97}$ On Tajikistan, the Committee recommended, in 2004, that it should apply its laws on citizenship without discrimination, 'as requested in Article 5(d)(iii) of the Convention'. ${ }^{98}$ In its next Concluding Observations, in 2012, the Committee reiterated this and simply recommended to 'resolve the problem of the stateless persons'. ${ }^{99}$ It has made similar remarks on the Croatian Citizenship Act, "which appears to establish different criteria in granting citizenship to ethnic Croats as compared to other "nationalities" in Croatia'. ${ }^{100}$ In particular, it was concerned that former long term residents of Serb origin and other minorities with 'pre-conflict attachment' to

95 Committee on the Elimination of Racial Discrimination, Consideration of Reports Submitted by States Parties under Article 9 of the Convention: Concluding Observations of the Committee on the Elimination of Racial Discrimination: Israel, UN Doc CERD/C/ISR/CO/13 (14 June 2007) [17], [20]; Committee on the Elimination of Racial Discrimination, Concluding Observations on the Combined Seventeenth to Nineteenth Reports of Israel, UN Doc CERD/C/ISR/CO/17-19 (27 January 2020) [16], [24], [25].

$96 S R G$, UN Doc CERD/C/2007/1 (n 25) [19].

97 Committee on the Elimination of Racial Discrimination, Concluding Observations on the Combined Fourteenth to Seventeenth Reports of Cambodia, UN Doc CERD/C/KHM/CO/1417 (30 January 2020) [25]-[26].

98 Committee on the Elimination of Racial Discrimination, Consideration of Reports Submitted by States Parties under Article 9 of the Convention: Concluding Observations of the Committee on the Elimination of Racial Discrimination: Tajikistan, UN Doc CERD/C/65/CO/8 (10 December 2004) [14].

99 Committee on the Elimination of Racial Discrimination, Concluding Observations on the Sixth to Eight Periodic Report of Tajikistan, Adopted by the Committee on the Elimination of Racial Discrimination at Its Eighty-First Session, UN Doc CERD/C/TJK/CO/6-8 (24 October 2012) [14] ('Concluding Observations: Tajikistan').

100 Committee on the Elimination of Racial Discrimination, Consideration of Reports Submitted by States Parties under Article 9 of the Convention: Concluding Observations of the Committee on the Elimination of Racial Discrimination: Croatia, UN Doc CERD/C/60/CO/4 (22 February 2002) [14] ('Concluding Observations: Croatia'), citing Croatian Citizenship Act (1991) Official Gazette NN 53/91, 70/91, 28/92, 113/93, 4/94, 130/11, 110/15 (Croatia). 
Croatia were unable to 'reclaim their status as citizens and/or residents'. ${ }^{101}$ It raised a similar concern on Bosnia and Herzegovina, and noted with concern that the grounds for denying citizenship were 'vague and may lead to discriminatory application'. ${ }^{102}$ Such vagueness and the risk of (indirect) discrimination as a result has also been noted by the Committee in relation to Switzerland and Cyprus, among others. ${ }^{103}$

The Committee has been clearest when one particular group is directly excluded from citizenship. The UAE, Kuwait and Saudi Arabia are three countries with a sizeable population of Bidoon, a traditionally nomadic group, many of whom are stateless. ${ }^{104}$ The Committee made note of this in the latest Concluding Observations of the UAE and Kuwait, recommending the latter to consider 'naturalizing those who have lived in Kuwait for long periods and have a genuine and effective link to the State'. ${ }^{105}$ It did not raise this issue on Saudi Arabia, although it did mention statelessness as a result of gender discrimination. ${ }^{106} \mathrm{On}$ Kenya, the Committee urged the state to address its discriminatory procedures towards the Nubian minority such as extensive vetting procedures and 'to consider awarding Kenyan citizenship to all Nubians who were residing in Kenya on the date of Kenyan independence and their descendants'.107

\section{Public Authorities and Public Institutions}

While local officers are pivotal in the administrative practices, discretion to determine the outcome of naturalisation processes — often without judicial oversight — could lead to denial of nationality and the risk of statelessness, especially in situations where a minority group already faces social stigma in their home country. ${ }^{108}$ Article 7 of the ICERD stipulates that states should combat

101 Committee on the Elimination of Racial Discrimination, Consideration of Reports Submitted by States Parties under Article 9 of the Convention: Concluding Observations of the Committee on the Elimination of Racial Discrimination: Croatia, $53^{\text {rd }}$ sess, UN Doc CERD/C/304/Add.55 (10 February 1999) [11], [17]; Concluding Observations: Croatia, UN Doc CERD/C/60/CO/4 (n 100) [100].

102 Committee on the Elimination of Racial Discrimination, Concluding Observations on the Ninth to Eleventh Periodic Reports of Bosnia and Herzegovina, UN Doc CERD/C/BIH/CO/911 (12 June 2015) [10].

103 Committee on the Elimination of Racial Discrimination, Concluding Observations on the Combined Seventh to Ninth Periodic Reports of Switzerland, UN Doc CERD/C/CHE/CO/79 (13 March 2014) [13]; Committee on the Elimination of Racial Discrimination, Concluding Observations on the Seventeenth to Twenty-Second Periodic Reports of Cyprus, Adopted by the Committee at Its Eighty-Third Session, UN Doc CERD/C/CYP/CO/17-22 (23 September 2013) [18].

104 Institute of Statelessness and Inclusion (n 1) 109-11.

105 Committee on the Elimination of Racial Discrimination, Concluding Observations on the Combined Twenty-First to Twenty-Fourth Periodic Reports of Kuwait, UN Doc CERD/C/KWT/CO/21-24 (25 August 2017) [27]-[28] ('Concluding Observations: Kuwait'); Committee on the Elimination of Racial Discrimination, Concluding Observations on the Eighteenth to Twenty-First Periodic Reports of the United Arab Emirates, UN Doc CERD/C/ARE/CO/18-21 (25 August 2017) [27]-[30] ('Concluding Observations: UAE'); Committee on the Elimination of Racial Discrimination, Consideration of Reports Submitted by States Parties under Article 9 of the Convention: Concluding Observations of the Committee on the Elimination of Racial Discrimination: United Arab Emirates, UN Doc CERD/C/ARE/CO/17 (31 August 2009) [17].

106 Committee on the Elimination of Racial Discrimination, Concluding Observations on the Combined Fourth to Ninth Periodic Reports of Saudi Arabia, UN Doc CERD/C/SAU/CO/49 (8 June 2019) [29] ('Concluding Observations: Saudi Arabia').

107 Concluding Observations: Kenya, UN Doc CERD/C/KEN/CO/5-7 (n 74) [27], [29].

108 De Chickera and Whiteman (n 8) 104. 
prejudices and promote understanding among different groups. 109 General Recommendation No 13 acknowledges the role of 'public authorities and public institutions, national and local', in guaranteeing the rights identified under art 5, and that 'law enforcement officials should receive intensive training' to do so. ${ }^{110}$ In relation to this, it is worth reiterating that in art 2 on obligations, the ICERD requires states to take active measures to combat racial discrimination. Building on this, the Committee calls upon states parties to report on measures taken for training of law enforcement in the elimination of racial discrimination, when preparing its periodic state report. ${ }^{111}$

The state is responsible for ensuring that its public authorities comply with the ICERD. However, during the assessment of Concluding Observations and individual complaints, no communications were found that challenged the discretion of public authorities in determining nationality itself, even if the chances were high that it would lead to discrimination and arbitrariness. On the naturalisation procedure, the Committee has made recommendations to ensure 'standardized registration procedures' or 'legal safeguards'. ${ }^{112}$ However, it has not been consistent in the way it phrases such recommendations. To countries with particular problems regarding prejudices and the right to nationality, such as Madagascar, Thailand, Lebanon and Kuwait, the Committee has not mentioned discrimination as a result of such prejudices, although it did in these cases raise other issues related to nationality. ${ }^{113}$

Switzerland provides another interesting case study. It includes in its naturalisation procedure a popular vote to determine if a person should obtain citizenship in a number of its states (Cantons). In 2002, the Committee noted that 'it was concerned at expressions of xenophobic and racist attitudes' in these procedures. ${ }^{114}$ When an applicant of Albanian origin was rejected for Swiss nationality by popular vote, he submitted a complaint to the Committee claiming that he was rejected because of his national origin. While the Committee declared the case inadmissible as 'discrimination on the grounds of national or ethnic

109 ICERD (n 3) art 7.

110 Committee on the Elimination of Racial Discrimination, General Recommendation 13 on the Training of Law Enforcement Officials in the Protection of Human Rights, UN Doc A/49/18 (16 March 1993) [1]-[2].

$111 S R G, \mathrm{UN}$ Doc CERD/C/2007/1 (n 25) [19].

112 Concluding Observations: Kenya, UN Doc CERD/C/KEN/CO/5-7 (n 74) [27], [29].

113 De Chickera and Whiteman (n 8) 104; Committee on the Elimination of Racial Discrimination, Consideration of Reports Submitted by States Parties under Article 9 of the Convention: Concluding Observations of the Committee on the Elimination of Racial Discrimination: Madagascar, UN Doc CERD/C/65/CO/4 (10 December 2004) [15] ('Concluding Observations: Madagascar'); Committee on the Elimination of Racial Discrimination, Concluding Observations on the Eighteenth to Twenty-Second Periodic Reports of Lebanon, UN Doc CERD/C/LBN/CO/18-22 (26 August 2016) [23] ('Concluding Observations: Lebanon'); Committee on the Elimination of Racial Discrimination, Concluding Observations on the First to Third Periodic Reports of Thailand, Adopted by the Committee at Its Eighty-First session, UN Doc CERD/C/THA/CO/1-3 (15 November 2012) [14] ('Concluding Observations: Thailand').

114 Committee on the Elimination of Racial Discrimination, Consideration of Reports Submitted by States Parties under Article 9 of the Convention: Concluding Observations of the Committee on the Elimination of Racial Discrimination: Switzerland, UN Doc $\mathrm{CERD} / \mathrm{C} / 60 / \mathrm{CO} / 14$ (21 May 2002) [10]. 
grounds has not been proven', it noted that such a popular vote should not discriminate on one of the grounds of discrimination. ${ }^{115}$

\section{Gender discrimination}

According to the Special Rapporteur on Minority Issues, 'women belonging to minorities may be further marginalized by gender-based discrimination in relation to the acquisition, change or retention of nationality and the conferral of nationality on their children'. ${ }^{116}$ This applies, among others, to the 25 states worldwide that have laws in place that deny women from transferring nationality to their children, posing one of the root causes of statelessness in these countries. ${ }^{117}$ As previously mentioned, the Committee emphasises the need to pay attention to 'complex forms of disadvantage', which is particularly true for the relation between gender and racial discrimination. ${ }^{118}$ This is mentioned in the ICERD's preamble, considering that it is one of the United Nations' purposes to oversee human rights without distinction as to 'race, sex, language or religion'. 119 In its General Recommendation No 25, the Committee emphasised the importance of 'gender-related dimensions of racial discrimination'. ${ }^{120}$ In GR 30, it specifically mentioned 'allowing both parents to transmit their citizenship to their children' as a measure to reduce statelessness. ${ }^{121}$ In its Concluding Observations, the Committee noted that women married to foreign men do not pass their nationality on an equal basis to men married to foreign women, in countries including Saudi Arabia, Jordan, Bahrain, UAE, Kuwait and Nigeria. ${ }^{122}$ It recommended that Madagascar revise its nationality law to ensure that Malagasy women can transfer their nationality to their children on an equal footing as men. ${ }^{123}$ While at first sight, these recommendations seem to be about discrimination on gender more than on race or other ground under the ICERD, the Committee makes, both implicitly and explicitly, reference to discrimination against the husband on the ground of national origin in most of these communications.

115 Committee on the Elimination of Racial Discrimination, Opinion Adopted by the Committee under Article 14 of the Convention, Concerning Communication No 53/2013, UN Doc CERD/C/91/D/53/2013 (23 January 2017) [6.2], [7.6].

116 Fernand de Varennes, Report of the Special Rapporteur on Minority Issues, $57^{\text {th }}$ sess, Agenda item 3, UN Doc A/HRC/37/66 (16 January 2018) [37].

117 Statelessness and Human Rights: The Convention on the Elimination of All Forms of Discrimination against Women (Report, Institute on Statelessness and Inclusion 2017). For more information, see Global Campaign for Equal Nationality Rights (Web Page) $<$ https://equalnationalityrights.org/ $>$.

$118 S R G, \mathrm{UN}$ Doc CERD/C/2007/1 (n 25) arts 5(II)(B) [19].

$119 \operatorname{ICERD}$ (n 3) preamble.

120 GR 25, UN Doc CERD/C/GC/25 (n 26).

$121 G R$ 30, UN Doc CERD/C/64/Misc.11/Rev.3 (n 13) [16]. This was reiterated in the GR 25, UN Doc CERD/C/GC/25 (n 26) [19].

122 Concluding Observations: Saudi Arabia, UN Doc CERD/C/SAU/CO/4-9 (n 106) [29]; Concluding Observations: Jordan, UN Doc CERD/C/JOR/CO/18-20 (n 51) [22]; Committee on the Elimination of Racial Discrimination, Consideration of Reports Submitted by States Parties under Article 9 of the Convention, Concluding Observation of the Committee on the Elimination of Racial Discrimination: Bahrain, UN Doc CERD/C/BHR/CO/7 (14 April 2005) [25]; Concluding Observations: Kuwait, UN Doc CERD/C/KWT/CO/21-24 n 105) [27]-[28]; Concluding Observations: UAE, UN Doc CERD/C/ARE/CO/18-21 (n 105) [30]; Committee on the Elimination of Racial Discrimination, Consideration of Reports Submitted by States Parties under Article 9 of the Convention: Concluding Observations of the Committee on the Elimination of Racial Discrimination: Nigeria, UN Doc CERD/C/NGA/CO/18 (27 March 2007) [21].

123 Concluding Observations: Madagascar, UN Doc CERD/C/65/CO/4 (n 113) [15]. 
In conclusion, where deprivation of nationality is an explicit 'breach of States Parties' obligations', GR 30 recommends states to ensure non-discrimination with regard to access to citizenship or naturalisation. ${ }^{124}$ The Concluding Observations show that there are cases in which the Committee seems to suggest that not granting citizenship on the basis of a person's race, colour, descent and national or ethnic origin is a breach of the ICERD, in particular, when it is clear that the group or member of such group that is discriminated against has a genuine and effective link to that state. The Committee seems to have a strong focus on result, rather than the form. Concerning ethnicity included in citizenship legislation, the formulation that the Committee uses to emphasise non-discrimination indicates that the Committee is most concerned with the outcome of legislation. The Committee tolerates legislation that includes ethnicity to a limited extent where it does not lead to major issues of statelessness, but obliges states to ensure that differentiating provisions 'do not give rise to discrimination'. ${ }^{125}$ In the next Part, we will look at further measures member states should take to eliminate statelessness.

\section{Positive Obligations to Eliminate Statelessness}

The key article on obligations in the ICERD is art 2, which calls for special and concrete measures. Taking pro-active actions is required as, in many cases, being a minority goes hand-in-hand with socio-economic or other disadvantages, which in itself could put individuals at risk of statelessness. ${ }^{126}$ Circumstances can prevent certain groups protected under the ICERD from obtaining citizenship, be it through lack of documentation, illiteracy of its members or disadvantages that make certain groups more vulnerable to statelessness. For example, in states where proof of birth on its territory or other specific documentation is needed in the application procedure for citizenship, individuals may be refused citizenship despite being eligible for it. ${ }^{127}$

Generally, the right to nationality under the ICERD entails a duty to, as the Committee states in its $G R$ 30, 'reduce statelessness, in particular statelessness among children'.128 One recommendation by the Committee to reduce statelessness is to ratify and implement the Statelessness Conventions. ${ }^{129}$ In some cases, reducing statelessness among disadvantaged groups might entail taking measures that target these specific groups, to which the ICERD could be a potential tool. Positive measures could be required when it comes to the right to nationality. More is needed beyond focusing on stateless persons' lack of nationality, and attention ought to be drawn to equal access to rights in general. ${ }^{130}$

124 GR 30, UN Doc CERD/C/64/Misc.11/Rev.3 (n 13) [4].

125 Concluding Observations: DRC, UN Doc A/62/18 (n 91) [331].

126 De Chickera and Whiteman (n 8) 113.

127 Institute of Statelessness and Inclusion (n 1) 26-27.

128 GR 30, UN Doc CERD/C/64/Misc.11/Rev.3 (n 13) [16].

129 Committee on the Elimination of Racial Discrimination, Concluding Observations on the Combined Twelfth and Thirteenth Periodic Reports of Bosnia and Herzegovina, UN Doc $\mathrm{CERD} / \mathrm{C} / \mathrm{BIH} / \mathrm{CO} / 12-13$ (10 September 2018) [30](f); Committee on the Elimination of Racial Discrimination, Concluding Observations on the Combined Twenty-Second to TwentyFourth Periodic Reports of Poland, UN Doc CERD/C/POL/CO/22-24 (24 September 2019) [25].

130 De Chickera and Whiteman (n 8) 107. 
In general international human rights discourse, states have, next to respecting and protecting the human rights of persons under their jurisdiction, a duty to fulfil the rights under the ICERD. ${ }^{131}$ The HRC stipulates that states have an obligation to 'adopt legislative, administrative, educative and other appropriate measures in order to fulfil their legal obligations' with regard to the civil and political rights outlined in the ICCPR. ${ }^{132}$ On the right to nationality, it states in General Comment No 17 that states are 'required to adopt every appropriate measure ... to ensure that every child has a nationality when he is born'. ${ }^{133}$ The $C R C$ provides similar guidance on how to facilitate the right to nationality to children. ${ }^{134}$ The Committee on the Elimination of Discrimination against Women adopted General Recommendation No 25 on 'temporary special measures' under art 4(1) of the $C E D A W$, in which it requires states to take measures 'to accelerate the improvement of the position of women to achieve their de facto or substantive equality with men'. 135 The 1954 Convention stipulates that states should facilitate naturalisation and 'in particular make every effort to expedite naturalisation proceedings and to reduce as far as possible the charges and costs of such proceedings'. 136

The ICERD prescribes a broad array of measures to ensure the goal of equal access to the rights identified in art 5 and requires states to pursue equal access to nationality 'by all appropriate means', which could include taking 'special and concrete measures'. ${ }^{137}$ Furthermore, General Recommendation No 25 clarifies that states have a positive obligation to correct existing inequalities of certain groups. ${ }^{138}$ In only a few of its Concluding Observations, the Committee gets concrete on what exact steps states should take in order to fulfil the right to a nationality. For example, on Georgia, it recommended:

'that the State Party take effective measures to reduce the risk of statelessness and ensure that all stateless persons, including children born in the State Party who would otherwise be stateless, are granted nationality without undue administrative obstacles'. ${ }^{139}$

131 Frédéric Mégret, 'Nature of Obligations' in Daniel Moeckli, Sangeeta Shah and Sandesh Sivakumaran (eds), International Human Rights Law ( $1^{\text {st }}$ edn, Oxford University Press 2010) 131.

132 United Nations Human Rights Committee, General Comment No 31: The Nature of the General Legal Obligation Imposed on States Parties to the Covenant, UN Doc CCPR/C/21/Rev.1/Add.13 (26 May 2004) [7].

133 GC 17 UN Doc HRI/GEN/1/Rev.9 (n 79) [8].

134 CRC (n 7) art 7(1). In its General Comment 7, the Committee on the Rights of the Child recommends that 'States Parties take all necessary measures to ensure that all children are registered at birth'. United Nations Committee on the Rights of the Child, General Comment No 7 (2005): Implementing Child Rights in Early Childhood, UN Doc CRC/C/GC/7/Rev.1 (20 September 2006) [25].

135 Committee on the Elimination of All Forms of Discrimination against Women, General Recommendation No 25, on Article 4, Paragraph 1, of the Convention on the Elimination of All Forms of Discrimination against Women, on Temporary Special Measures, UN Doc HRI/GEN/1/Rev.7 (12 May 2004) [15]; CEDAW (n 7) art 4(1).

1361954 Convention (n 5) art 32.

$137 \operatorname{ICERD}(\mathrm{n} 3)$ art 2.

138 GR 32, UN Doc CERD/C/GC/32 (n 21).

139 Committee on the Elimination of Racial Discrimination, Concluding Observation on the Sixth to Eighth Periodic Reports of Georgia, UN Doc CERD/C/GEO/CO/6-8 (13 May 2016) [22]. 
On Kazakhstan and other states in the region, it simply recommended to 'take measures to address statelessness'. ${ }^{140}$ Despite the general nature of such recommendations, they could be seen as a starting point that obligations regarding the right to nationality is not interpreted as only abstaining from violations. Moreover, the Committee has also recommended states to ensure stateless persons have access to health care, education and employment services. ${ }^{141}$

In particular, the Committee has used its group-specific General Recommendations to emphasise the call for positive measures. On 'racial discrimination against people of African descent', it 'observes that overcoming the structural discrimination ... calls for the urgent adoption of special measures'. ${ }^{142}$ In order to improve the situation of Roma communities, the Committee recommended taking a number of special measures to improve living conditions and participation in public life, on top of a list of other 'regular' measures. ${ }^{143}$ For instance, it recommended the Russian Federation improve the socio-economic situation of Roma communities by special measures to facilitate their access to, inter alia, citizenship. ${ }^{144}$ It made a similar comments on Roma populations in Lithuania and Macedonia, among others. ${ }^{145}$ Judging from this language, solving statelessness is more than a goal in itself; it is, rather, an acknowledgment that citizenship is needed to improve the situation of particular groups. Having established that there is indeed an obligation to actively ensure equal enjoyment of the right to a nationality, it would be interesting to see then what sort of measures countries are required to take.

140 Committee on the Elimination of Racial Discrimination, Concluding Observations on the Combined Sixth and Seventh Periodic Reports of Kazakhstan, UN Doc CERD/C/KAZ/CO/67 [19]; Committee on the Elimination of Racial Discrimination, Concluding Observations on the Combined Eighth and Ninth Periodic Reports of Uzbekistan, UN Doc CERD/C/UZB/CO/8-9 (14 March 2014) [20]; Concluding Observations: Tajikistan, UN Doc CERD/C/TJK/CO/6-8 (n 99) [14]; Committee on the Elimination of Racial Discrimination, Consideration of Reports Submitted by States Parties under Article 9 of the Convention: Concluding Observations: Turkmenistan, UN Doc CERD/C/TKM/CO/6-7 (13 April 2012) [17].

141 Committee on the Elimination of Racial Discrimination, Concluding Observations on the Combined Twenty-Third and Twenty-Fourth Periodic Reports of Magnolia, UN Doc CERD/C/MNG/CO/23-24 (17 September 2019) [15], [16].

142 GR 34, UN Doc CERD/C/GC/34 (n 86).

143 Committee on the Elimination of Racial Discrimination, General Recommendation No 27 on Discrimination against Roma, UN Doc A/55/18 (16 August 2000) annex V ('GR 27') [28], [29], [41].

144 Committee on the Elimination of Racial Discrimination, Concluding Observations on the Twentieth to Twenty-Second Periodic Reports of the Russian Federation, UN Doc CERD/C/RUS/CO/20-22 (1 March 2013) [15].

145 Committee on the Elimination of Racial Discrimination, Concluding Observations on the Combined Sixth to Eighth Periodic Reports of Lithuania, UN Doc CERD/C/LTU/CO/6-8 (6 January 2016) [22]; Committee on the Elimination of Racial Discrimination, Concluding Observations on the Combined Eighth to Tenth Periodic Reports of the Former Yuglosav Republic of Macedonia, UN Doc CERD/C/MKD/CO/8-10 (21 September 2015) [20]; Committee on the Elimination of Racial Discrimination, Consideration of Reports Submitted by States Parties under Article 9 of the Convention: Concluding Observations: Italy, UN Doc CERD/C/ITA/CO/16-18 [24]. 


\section{A Data Collection and Reporting}

In General Recommendation No 24 on art 1(1), the Committee asks states to report on non-citizens and to include information on demographics in their reporting. ${ }^{146}$ In its $S R G$ it also requests information on 'the specific situation of long-term or permanent residents' and on the action taken by the state. ${ }^{147}$ In its Concluding Observations, for example, the Committee requested Togo to 'provide in its next periodic report precise and disaggregated data on persons who have applied for Togolese nationality, the number of applications accepted, the number denied and, if applicable, the reasons for denial'. ${ }^{148}$ It has requested other states for similar data. ${ }^{149}$ During its Concluding Observations of Estonia in 2010, the Committee recommended the further examination of "the reasons behind the reluctance of potential applicants to engage in the naturalization process with a view to improving the situation'. ${ }^{150}$ During an earlier review of Estonia, the Committee already recommended 'a thorough investigation into possible barriers which may exist, both in terms of the naturalization procedure and in relation to lack of motivation to apply for citizenship'. ${ }^{151}$

\section{B Removal of Barriers to Naturalisation}

Most Concluding Observations by the Committee on proactive action seems to be about tearing down barriers. The Committee has, on the enjoyment of human rights more generally, referred to barriers, such as administrative, legal, practical, economic, social, geographic and linguistic. ${ }^{152}$ In its GR 30, the Committee has recommended that the states 'pay due attention to possible barriers of naturalisation' and 'encourage parents to apply for citizenship'. ${ }^{153}$ In its Concluding Observations, the Committee has noted that in Sri Lanka, Tamils of Indian origin face such structural inequalities in the form of, inter alia, high levels of poverty, poor housing conditions, and 'difficulty in obtaining citizenship papers or identity documents, leading to problems with owning housing, opening bank

146 Committee on the Elimination of Racial Discrimination, General Recommendation No 24 Concerning Article 1 of the Convention, 55 ${ }^{\text {th }}$ sess, $1371 \mathrm{mtg}$, UN Doc A/54/18, annex V (27 August 1999) [3]-[4]; GR 30, UN Doc CERD/C/64/Misc.11/Rev.3 (n 13) [5].

147 SRG, UN Doc CERD/C/2007/1 (n 25) [19].

148 Concluding Observations: Togo, UN Doc CERD/C/TGO/CO/18-19 (n 60) [27].

149 Committee on the Elimination of Racial Discrimination, Consideration of the Reports Submitted by States Parties under Article 9 of the Convention: Concluding Observations of the Committee on the Elimination of Racial Discrimination: Uzbekistan, UN Doc CERD/C/UZB/CO/5 (10 March 2006) [19]; Concluding Observations: Turkmenistan, UN Doc CERD/C/TKM/CO/5 (n 49) [9]; Committee on the Elimination of Racial Discrimination, Consideration of Reports Submitted by States Parties under Article 9 of the Convention: Concluding Observations of the Committee on the Elimination of Discrimination: Australia, UN Doc CERD/C/AUS/CO/14 (11 March 2005) [24].

150 Committee on the Elimination of Racial Discrimination, Consideration of Reports Submitted by States Parties under Article 9 of the Convention: Concluding Observations of the Committee on the Elimination of Racial Discrimination: Estonia, UN Doc CERD/C/EST/CO/8-9 ( 27 August 2010) [15].

151 Committee on the Elimination of Racial Discrimination, Report of the Committee on the Elimination of Racial Discrimination: Concluding Observations of the Committee on the Elimination of Racial Discrimination: Estonia, UN Doc A/57/18 (22 August 2002) [353].

152 Thornberry (n 19) 88.

153 GR 30, UN Doc CERD/C/64/Misc.11/Rev.3 (n 13) [13], [16]; $\quad G R \quad 34, \quad$ UN Doc CERD/C/GC/34 (n 86) [47]. 
accounts and avoiding detention'. ${ }^{154}$ After welcoming the measures taken by Iraq to reinstate the citizenship of Faili Kurds, who were stripped of their Iraqi citizenship in the 1980 s, the Committee recommended that the state party accelerate the process of reinstating Faili Kurds' citizenship by facilitating their access to citizenship, including by removal of all administrative obstacles throughout the process. ${ }^{155}$

Lack of birth registration in particular is, as the Committee acknowledged, 'a contributing factor to statelessness'. ${ }^{156}$ In the Concluding Observations of Lebanon, the Committee recommended that the state party ensures that birth registration is accessible to all children born in its jurisdiction, 'including by removing financial, procedural and regulatory obstacles'. ${ }^{157}$ Similarly, it was 'concerned at the requirement in the State Party for parents to present residence registration papers before the issuance of a birth certificate for their child', which leads to difficulties for already disadvantaged groups. ${ }^{158}$ On Suriname, the Committee recommended 'that the State Party remove administrative barriers and discriminatory practices ... to prevent statelessness and address discriminatory practices ... particularly in the context of birth registration'. ${ }^{159}$

\section{Refugees and Displaced Persons}

Facilitated naturalisation has been identified as a possible durable solution of statelessness in the refugee-context, where the person cannot make use of the nationality of their home country. ${ }^{160}$ The Committee has published a General Recommendation specifically on refugees and displaced persons, which was primarily focused on non-refoulement and did not go in-depth on how the various rights under art 5 should be interpreted. ${ }^{161}$ In its Concluding Observations, the Committee has raised its concern over the large amount of long-term stateless refugees on the territory of Tajikistan and Rwanda and recommended to, at the very least, make refugees and asylum seekers aware of the law on nationality. ${ }^{162}$ The Committee has also recommended to 'develop a statelessness determination

154 Committee on the Elimination of Racial Discrimination, Concluding Observations on the Combined Tenth to Seventeenth Periodic Reports of Sri Lanka, UN Doc CERD/C/LKA/CO/10-17 (6 October 2016) [20].

155 Committee on the Elimination of Racial Discrimination, Concluding Observations on the Combined Twenty-Second to Twenty-Fifth Periodic Reports of Iraq, UN Doc $\mathrm{CERD/C/IRQ/CO/22-25} \mathrm{[33],} \mathrm{[36].}$

156 Concluding Observations: Thailand, UN Doc CERD/C/THA/CO/1-3 (n 113) [14].

157 Concluding Observations: Lebanon, UN Doc CERD/C/LBN/CO/18-22 (n 113) [23].

158 Committee on the Elimination of Racial Discrimination, Concluding Observations on the Combined Seventh to Ninth Periodic Reports of Azerbaijan, UN Doc CERD/C/AZE/CO/7-9 (10 June 2016) [31]-[32].

159 Committee on the Elimination of Racial Discrimination, Concluding Observations on the Thirteenth to Fifteenth Periodic Reports of Suriname, UN Doc CERD/C/SUR/CO/13-15 (28 August 2015) 20.

160 Tamás Molnár, 'A Fresh Examination of Facilitated Naturalisation as a Solution for Stateless Persons' in Laura van Waas and Melanie J. Khanna (eds), Solving Statelessness (Wolf Legal Publishers, 2016) 248, 248-252.

161 Committee on the Elimination of Racial Discrimination, General Recommendation No 22: Article 5 of the Convention on Refugees and Displaced Persons, UN Doc A/51/18 (24 August 1996) ('GR 22') [2].

162 Concluding Observations: Tajikistan, UN Doc CERD/C/TJK/CO/6-8 (n 99) [14]; Committee on the Elimination of Racial Discrimination, Concluding Observations on the Eighteenth to Twentieth Periodic Reports of Rwanda, UN Doc CERD/C/RWA/CO/18-20 (10 June 2016) [20]-[21]. 
procedure to adequately ensure the identification and protection of stateless persons'. ${ }^{163}$ States are recommended that 'facilitated naturalization of refugees and stateless persons' is a possible solution to their lack of nationality. ${ }^{164}$ While the Committee does not recommend this for all refugee-situations, it does seem to provide an opening for facilitated naturalisation as a durable solution for refugees and asylum-seekers at risk of statelessness.

To sum up, under the provisions of arts 2(1)(e) and 2(2) of the ICERD, States Parties have a positive obligation to work towards the elimination of racial discrimination. The Committee has made its strongest Concluding Observations on tearing down existing barriers to naturalisation, including hurdles in the application process that enforce an already existing inequality. States are recommended to take steps to enable anyone the access to nationality. Only in a few cases has the Committee recommended states to take special measures targeting one particular group. However, it does acknowledge that the very presence of non-citizens gives rise to an obligation towards these non-citizens.

\section{CONCLUSION}

As described in the introduction, racial discrimination is one of the main root causes of statelessness. Owing to its mandate to eliminate such discrimination in all its forms, the ICERD has the potential to ensure an effective nationality to every individual, regardless of their race, colour, descent, national or ethnic origin. ${ }^{165}$ As its monitoring body, the Committee has the mandate to promote the implementation of the ICERD through the periodic review of Member States, interpretations of particular provisions in the ICERD and other communications, and can, therefore, play a pivotal role in ensuring an equal enjoyment of the right to a nationality.

In its Concluding Observations, the Committee made references related to nationality, citizenship and statelessness in 145 out of 262 Concluding Observations from 2004-19. That is a clear sign that this issue is of relevance to the Committee. These recommendations are diverse and may range from a request to provide more data on a state party's naturalisation procedure, to urging them to recognise a particular group within the state party's jurisdiction as citizens. This paper aims to provide a clearer picture of how the Committee interprets the right to nationality, and whether there are gaps that needs to be solved.

Regarding the ICERD's mandate, the starting point is the Committee's consistent reference to its aim of eliminating 'all forms of racial discrimination', and providing for the rights listed in art 5 without racial discrimination. This builds onto the key art 1, defining racial discrimination, and art 2, which sets out the measures a member state should take to do so.

163 Committee on the Elimination of Racial Discrimination, Concluding Observations on the Combined Seventh to Ninth Periodic Reports of Japan, UN Doc CERD/C/JPN/CO/7-9 (29 August 2014) [23]; Committee on the Elimination of Racial Discrimination, Concluding Observations on the Combined Eight to Tenth Periodic Reports of Kyrgyzstan, UN Doc CERD/C/KGZ/CO/8-10 (30 May 2018) [30]; Committee on the Elimination of Racial Discrimination, Concluding Observations on the Combined Fifth to Ninth Reports of Ireland, UN Doc CERD/C/IRL/CO/5-9 (12 December 2019) [36].

164 Committee on the Elimination of Racial Discrimination, Concluding Observations on the Fourth to Sixth Periodic Reports of Liechtenstein, UN Doc CERD/C/LIE/CO/4-6 (31 August 2012) [14].

$165 \operatorname{ICERD~(n~3)~arts~1(1),~} 5$. 
In line with other international legal texts, arbitrary deprivation of citizenship is always in violation with the ICERD. However, GR 30 and following Concluding Observations show that in order not to be arbitrary, states must ensure that this revocation is non-discriminatory as one of the highest international standards. This applies to countries where dual nationality is not allowed, or where revocation of citizenship is used as a counter-terrorism measure. Also, denying the acquisition of citizenship can be a breach of the ICERD, in particular when it is clear that the group or member of such group that is discriminated against has a genuine and effective link to that state. States that connect ethnicity to their nationality identity, such as Israel, Croatia or Kenya, may include that aspect in their nationality legislation, strictly provided that this does not result in the exclusion of individuals not belonging to that ethnicity. Finally, states have an obligation to actively eliminate statelessness on their territory through the collection of data, active removal of barriers or the facilitation of naturalisation. The Committee uses its strongest and most concrete language on legislative developments, such as reform of nationality law or the establishment of a statelessness determination procedure. These type of Concluding Observations are measurable and concrete. On the implementation of legislation and procedures, it remains more vague and often recommends states parties to 'ensure' application without discrimination. How a state achieves this is left at the discretion, and good-will, of the state party.

The Committee upholds and pushes high normative standards regarding the right to nationality. As its monitoring body, while its communications do not constitute binding law, the Committee's interpretation of the ICERD carries great weight. ${ }^{166}$ While this paper does not give an in-depth analysis on the functioning of UN treaty bodies or the effectiveness of the reporting procedure across the UN system, it should be noted that, in reality, the request to submit a state report every two years is the exception, rather than the norm. ${ }^{167}$ In the 15 years since GR 30 was published, 262 periodic reviews have taken place by the Committee over its 182 member states. This results in a world-wide average of 1.44 such reviews per state. Based on this average, the Committee should have published Concluding Observations on all 182 state parties once every 10 years. However, as mentioned in the introduction, while some countries have met with the Committee three or four times, other states parties did not submit a single report on the implementation of the ICERD. These countries include smaller states that have less resources available to submit a report and send a delegation to Geneva, such as Nauru, Palau and Sao Tome and Principe. However, countries such as Singapore or Eritrea have yet to meet with the Committee for the first time. As mentioned previously, other countries including Liberia and Sierra Leone have not been under review since 2001 and 1996 respectively. Côte D'Ivoire, topping UNHCR's statelessness statistics with close to one million registered stateless persons, has not been reviewed since 2003. ${ }^{168}$ This makes it more difficult for the Committee to followup on its recommendations. As said, the most concrete recommendations by the

166 Ahmadou Sadio Diallo (Republic of Guinea v Democratic Republic of Congo) (Judgment) [2010] ICJ Rep 639 [66]. For a deeper review of this case, see Sandy Ghandhi, Human Rights and the International Court of Justice: The Ahmadou Sadio Diallo Case (2011) 11(3) Human Rights Law Review 527.

167 ICERD (n 3) art 9.

168 Global Trends: Forced Displacement in 2019 (Report, United Nations High Commissioner for Refugees June 2020) $<$ https://www.unhcr.org/5ee200e37.pdf $>$. For a discussion on the data, see Statelessness in Numbers: 2020 (Report, Institute of Statelessness and Inclusion August 2020) $<$ https://files.institutesi.org/ISI_statistics_analysis_2020.pdf $>$. 
Committee centre around legislative changes, which are measurable, though its wording becomes less concrete when considering what other measures states ought to take to ensure that the elimination of racial discrimination is achieved.

While the Committee is clear that states should indeed take measures to address statelessness, it could benefit from more detailed guidelines on how far states should go to ensure the right to a nationality. Building on GR 30 and consequent Concluding Observations, one suggestion that could be further fleshed out is a general recommendation specific to statelessness, as it has done on people of African descent, Roma, indigenous peoples, refugees and displaced persons. ${ }^{169}$ Such a communication could give necessary guidance to the 182 state parties on the implementation of art 5(d)(iii) in relation to the obligations described under art 2 and, of equal importance, raise the profile of statelessness as a fundamental human rights issue spanning all corners of the globe. Discrimination lies at the heart of the world's largest statelessness situations. Most recently, this has been demonstrated by the developments in Assam, India, where the Indian citizenship of 1.9 million people has been cast in doubt since 2019. This, on top of situations surrounding the Rohingya in Myanmar and Bangladesh, the Bidoon in the Gulf and Dominicans of Haitian descent, underscores the relation between statelessness and discrimination. Building on the past and looking to the future, the Committee can play an even stronger role in addressing this discrimination and building towards the elimination of statelessness.

$169 G R$ 34, UN Doc CERD/C/GC/34 (n 86); GR 27, UN Doc A/55/18 (n 141); Committee on the Elimination of Racial Discrimination, General Recommendation No 23 on the Rights of Indigenous Peoples, UN Doc A/52/18 (18 August 1997) annex V; GR 22, UN Doc A/51/18 (n 159). 